\title{
STUDI PENENTUAN SUMUR RESAPAN SEBAGAI UPAYA PENGENDALIAN BANJIR DI KOTA PEKALONGAN BERBASIS SISTEM INFORMASI GEOGRAFIS
}

\author{
Thomas Triadi Putranto ${ }^{1}$, Hadiyanto ${ }^{2}$, Asri Cahaya Hati ${ }^{3}$ \\ ${ }^{1}$ Fakultas Teknik, Teknik Geologi, Universitas Diponegoro \\ J1. Prof Soedharto SH, Tembalang, Semarang 50275 \\ ${ }^{2,3}$ Sekolah Pasca Sarjana, Magister Ilmu Lingkungan, Universitas Diponegoro \\ Jl. Imam Bardjo SH, Semarang 50241 \\ Korespondensi: putranto@,ft.undip.ac.id
}

\begin{abstract}
Population and socio-economic growth trigger changes in land use functions. Land use and climate change in line with the increase in the rate of surface water and a decrease in the quality of water infiltration into the soil. Decreasing water absorption triggers an abundance of water on the surface which leads to hydrometeorological disasters, one of them is flooding. The research study is in Pekalongan City which has a very flat topography and the estuary area of several rivers from the upstream area. The current condition of Pekalongan City has a huge potential for flood disaster. The purposes of this study are to measure the depth of the groundwater level, to delineate the flooding area, and to recommend the infiltration wells based on the Geographic Information System. The methods were hydrogeological mapping, including the measurement of the water table, collecting land use maps, delineating flooding zone, calculating impermeable zones, collecting hydrological data such as precipitation. The results show that the groundwater level at the research location is classified into 3 classes, namely 0-1.5 meters, 1.5-3 meters, and > 3 meters. The need for infiltration wells in the flood-prone areas of Pekalongan City is 57,718 units. The needs for rainwater infiltration wells in areas outside flood-prone areas and groundwater depth> 1.5 meters are 227,416 units with a well's depth between 1.5 to 4 meters.
\end{abstract}

Keywords: Infiltration well, hydrometeorological, disaster Pekalongan City

\section{PENDAHULUAN}

\subsection{Latar Belakang}

Kota Pekalongan memiliki luas wilayah $45,25 \mathrm{~km}^{2}$, yang terdiri dari 4 (empat) kecamatan (Gambar 1) dengan jumlah penduduk 304.477 jiwa (BPS, 2019). Kota Pekalongan memiliki potensi ekonomi pada sektor pertanian, perikanan, serta industri skala menengah dan kecil. Pertumbuhan penduduk dan sosial ekonomi mempunyai peranan penting dalam memicu kerusakan lingkungan hidup. Karena dapat menyebabkan perubahan fungsi tata guna lahan. Perubahan fungsi tata guna lahan dan perubahan iklim seiring dengan peningkatan laju air permukaan dan penurunan kualitas peresapan air ke dalam tanah. Penurunan kuantitas resapan air hujan memicu terjadinya peningkatan kuantitas air permukaan dan penurunan muka tanah di Kota Pekalongan
(Yulianto, dkk., 2019). Curah hujan Kota Pekalongan berkisar antara $1.647 \mathrm{~mm} /$ tahun hingga $3.461 \mathrm{~mm} /$ tahun dengan rata-rata curah hujan per tahunnya sebesar 2.180,40 mm (BPS, 2019). Hal ini dapat menyebabkan terjadinya bencana hidrometeorologi, salah satunya banjir (Pratama, 2019). Hampir di semua kecamatan Kota Pekalongan terjadi banjir yang diakibatkan genangan air hujan. Banjir menjadi potensi yang besar karena topografi wilayah Kota Pekalongan yang sangat datar dan merupakan kawasan muara dari beberapa sungai dari kawasan hulu di daerah lainnya.

Penanganan banjir yang sudah dilakukan belum optimal dan merupakan penyelesaian masalah jangka pendek. Tingkat banjir yang terjadi rata-rata sekitar $10-50 \mathrm{~cm}$ dengan ketinggian maksimum $70 \mathrm{~cm}$. Banjir hampir selalu terjadi selama 10 tahun terakhir (Kartika, 
dkk., 2019). Banjir yang merendam beberapa kelurahan di Kota Pekalongan dapat menyebabkan berbagai masalah bagi kesehatan masyarakat (Mitrović, dkk., 2019) bahkan kematian (George, 2011), kerugian ekonomi (Parida, 2019), dan gangguan psikologis yang serius (Yoda, dkk., 2017).

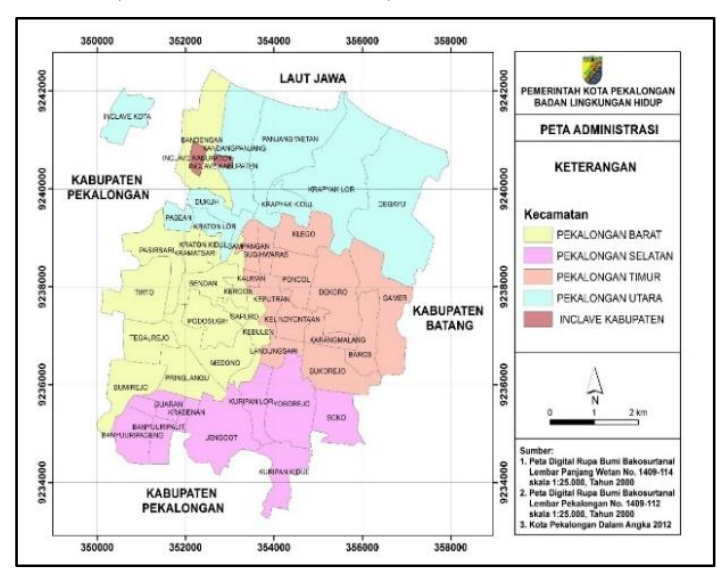

Gambar 1 Peta Administrasi

Kejadian banjir dari tahun ke tahun semakin bertambah. Hujan yang turun dengan kuantitas besar dan rentang waktu pendek pada area yang sudah terbangun menyebabkan tingginya volume genangan dan limpasan. Jika seluruh air hujan dialirkan melalui saluran air hujan (saluran drainase) yang ada ke sungaisungai tanpa diresapkan ke dalam tanah mengakibatkan terganggunya keseimbangan tata air dan hidro ekosistem (Muliawati and Mardyanto, 2015). Seperti pada penelitian Muliawati dan Mardyanto yang dilakukan di Kota Surabaya, konsep penerapan sumur resapan ini dilakukan karena sebagai pengganti tanah resapan yang mengalami pengerasan sehingga air tidak mampu meresap ke dalam tanah dengan efektif. Penelitian ini dilakukan untuk mengatasi daerah yang sering banjir di Kota Pekalongan. Aplikasi Sistem Informasi Geografis digunakan dalam penelitian di Kota Pekalongan untuk penentuan rekomendasi sumur resapan.

Tujuan dari penelitian ini untuk mengetahui kondisi kedalaman muka air tanah serta mengetahui karakteristik wilayah untuk menentukan titik dan rekomendasi sumur resapan untuk beberapa kecamatan. Rekomendasi sumur resapan disajikan dalam bentuk spasial berbasis Sistem Informasi Geografis (SIG).

\section{TINJAUAN PUSTAKA}

\subsection{Banjir}

Risiko bencana banjir berskala besar semakin meningkat dengan perubahan iklim. Suhu udara rata-rata telah meningkat secara global sebesar $0,72{ }^{\circ} \mathrm{C}$ sejak abad ke-19, dan di wilayah Asia Timur, peningkatan curah hujan yang tinggi terkait dengan banjir yang sering dapat menyebabkan kerusakan serius pada infrastruktur, mata pencaharian, dan permukiman (IPCC, 2014). Beberapa daerah di Pekalongan sudah di bawah rata-rata permukaan laut, kemungkinan besar sebagai dampak dari penurunan muka tanah. Dengan demikian, setelah laju penurunan muka tanah setahun, ketinggian genangan banjir meningkat pada kisaran $8-14 \mathrm{~cm}$.

\subsection{Resapan Air}

Kawasan resapan air secara kontinyu mengalami penurunan maka timbul berbagai permasalahan lingkungan, seperti tingginya volume air larian permukaan atau limpasan sebagai pemicu terjadinya bencana banjir. Kondisi resapan air di Kota Pekalongan (Gambar 2) yaitu kondisi agak kritis (16\%) dan kondisi mulai kritis (84\%) (Adibah, dkk., 2013).

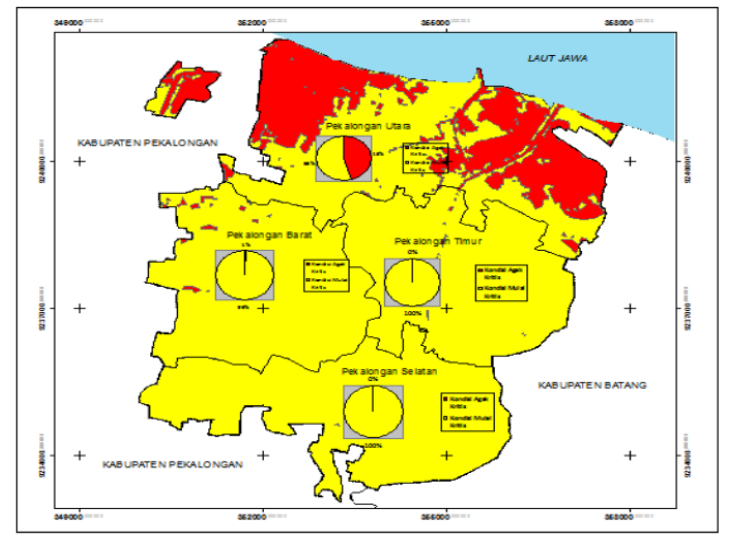

Gambar 2 Peta Resapan Air

Berdasarkan SNI 8456:2017 mengenai sumur dan parit resapan air hujan, bahwa persyaratan umum yang harus dipenuhi kaitannya dengan sumur resapan yaitu: 
a) Sumur resapan dan parit resapan air hujan ditempatkan pada lahan yang relatif datar dengan kemiringan maksimum $<2 \%$;

b) Air yang masuk ke dalam sumur resapan dan parit resapan adalah limpasan air hujan;

c) Penempatan sumur dan parit resapan air hujan harus mempertimbangkan keamanan bangunan sekitarnya;

d) Sumur resapan dan parit resapan air hujan bisa dibuat secara individual dan komunal;

e) Harus memperhatikan peraturan daerah setempat;

f) Hal-hal yang tidak memenuhi ketentuan ini harus disetujui oleh instansi yang berwenang.

Persyaratan teknis lainnya juga diatur dalam pembuatan sumur resapan, di antaranya yaitu:

a) Sumur resapan air hujan yang digunakan untuk kedalaman muka air tanah $>2 \mathrm{~m}$, jika kedalaman muka air tanah $<2 \mathrm{~m}$ bisa menggunakan parit resapan air hujan.

b) Penampang sumur resapan air hujan berbentuk segi empat atau lingkaran, dimungkinkan untuk bentuk lainnya dengan memperhatikan kemudahan dalam pengerjaan;

c) Ukuran sisi penampang sumur resapan air hujan $80 \mathrm{~cm}$ sampai dengan $100 \mathrm{~cm}$;

d) Permeabilitas tanah

Struktur tanah yang dapat digunakan harus mempunyai nilai koefisien permeabilitas tanah > $2.0 \mathrm{~cm} / \mathrm{jam}$, dengan klasifikasi dalam Error! Reference source not found. sebagai berikut:

Tabel 1 Nilai koefisien permeabilitas tanah

\begin{tabular}{ccc}
\hline $\begin{array}{c}\text { Koefisien } \\
\text { Permeabilitas } \\
\text { Tanah }\end{array}$ & Nilai & $\begin{array}{c}\text { Jenis } \\
\text { Tanah }\end{array}$ \\
\hline Sedang & $\begin{array}{c}2,0-3,6 \mathrm{~cm} / \mathrm{jam} \\
\text { atau } 0,48-0,864 \\
\mathrm{~m}^{3} / \mathrm{m}^{2} / \mathrm{hari}\end{array}$ & Lanau \\
& $\begin{array}{c}3,6-36 \mathrm{~cm} / \mathrm{jam} \\
\text { atau } 0,864-8,64 \\
\mathrm{~m}^{3} / \mathrm{m}^{2} / \mathrm{hari}\end{array}$ & Pasir halus \\
Agak Cepat & \\
& $>36 \mathrm{~cm}^{3} / \mathrm{jam}$ atau & Pasir kasar \\
Cepat & $8,64 \mathrm{~m}^{3} / \mathrm{m}^{2} / \mathrm{hari}$ & \\
&
\end{tabular}

e) Periode ulang hujan yang digunakan untuk perencanaan 2 tahun sekali terlampaui; f) Intensitas hujan ditentukan dengan analisis Intensity Duration Frequency (IDF) dari daerah lokasi pembangunan dengan durasi hujan 2 jam dan periode ulang 2 tahunan, dengan perhitungan dengan rumus sebagai berikut:

Metode Mononobe

$$
I=\frac{R_{24}}{24}\left(\frac{24}{t}\right)^{\frac{2}{3}} \text {. }
$$

\section{Keterangan}

I : Intensitas curah hujan ( $\mathrm{mm} / \mathrm{jam})$

$\mathrm{T}$ : Lamanya curah hujan/durasi curah hujan (jam)

$\mathrm{R}_{24}$ : Curah hujan rencana dalam suatu periode ulang, yang nilainya didapat dari tahapan sebelumnya (tahapan analisis frekuensi)

g) Koefisien limpasan (c) ditetapkan sebesar 0,95 .

h) Luas bidang tadah yang mempunyai kemiringan seperti atap rumah ditetapkan sebagi luas bidang proyeksi.

i) Debit limpasan dihitung dengan metode rasional dengan parameter koefisien limpasan (c), intensitas hujan dan luas bidang tadah;

j) Rumus yang dapat digunakan untuk perhitungan kedalaman sumur $(\mathrm{H})$ dapat dilihat pada persamaan:

$H=\frac{Q}{\omega \pi r K}$.

Harga $\omega=2$, untuk sumur kosong berdinding kedap air atau sumur tanpa dinding dengan batu pengisi

Harga $\omega=5$, untuk sumur kosong berdinding porus.

Keterangan:

$\mathrm{H}$ : kedalaman parit $(\mathrm{m})$

$\mathrm{R}$ : panjang parit $(\mathrm{m})$

$\mathrm{K}$ : lebar parit $(\mathrm{m})$

$\mathrm{Q}$ : debit andil banjir $(\mathrm{Q}=$ C.I.A $)$ $\left(\mathrm{m}^{3} / \mathrm{jam}\right)$

k) Pipa outlet dan pipa inlet serta pipa pelimpah untuk mengalirkan kelebihan air atau genangan dan masuk ke sumur resapan digunakan bahan pipa PVC minimal 3 inchi, sedangkan untuk inlet ke parit resapan air hujan dapat digunakan 
pipa PVC minimal 4 inci atau buis beton $1 / 230 \mathrm{~cm}$ (gravel) atau buis beton $30 \mathrm{~cm}$;

1) Pipa ventilasi (air outlet) pada sumur maupun parit resapan mempunyai konstruksi yang rapat maka diperlukan pipa pembuang udara dari PVC $1 / 2$ inchi untuk mencegah terhalangnya aliran dari debit andil banjir ke dalam sumur maupun parit resapan;

m) Jarak penempatan sumur dan parit resapan air hujan terhadap bangunan, dapat dilihat pada Error! Reference source not found. berikut:

Tabel 2 Jarak minimum sumur dan parit resapan air hujan terhadap bangunan

\begin{tabular}{cccc}
\hline No & Jenis Bangunan & $\begin{array}{c}\text { Sumur } \\
\text { Resapan } \\
\text { Air Hujan } \\
(\mathbf{m})\end{array}$ & $\begin{array}{c}\text { Parit } \\
\text { Resapan } \\
\text { Air Hujan } \\
(\mathbf{m})\end{array}$ \\
\hline 1 & $\begin{array}{c}\text { Pondasi bangunan/ } \\
\text { tangki septik }\end{array}$ & 1 & 1 \\
2 & $\begin{array}{c}\text { Bidang resapan/ } \\
\text { sumur resapan } \\
\text { tangki septik } \\
3\end{array}$ & 5 & 5 \\
Sumur resapan air \\
hujan/ sumur air \\
bersih
\end{tabular}

\subsection{Geologi dan Hidrogeologi}

Berdasarkan Peta Geologi Lembar Banjarnegara-Pekalongan (Condon, dkkl., 1996), daerah penelitian didominasi oleh endapan aluvium dengan litologi berupa kerikil, pasir, lempung, lanau, endapan sungai dan endapan rawa yang tersebar secara menyeluruh (Gambar 3). Dengan morfologi dataran (0-2\%) dan sedikit bergelombang (3-7\%) menurut Van Zuidam, 1983.

Kota Pekalongan termasuk ke dalam Cekungan Air Tanah (CAT) Pekalongan Pemalang (Putranto, dkk., 2016). Berdasarkan Peta Hidrogeologi Lembar Pekalongan (Effendi, 1985), sistem akuifernya aliran air tanah melalui ruang antar butir dengan jenis produktivitas akuifer yaitu akuifer produktif dengan persebaran luas: Akuifer dengan aliran melalui ruang antar butir, akuifer ini tersusun oleh formasi aluvium yang terdiri atas material berukuran lempung, lanau, pasir, kerikil dan brangkal dengan nilai kelulusan 2,68 m/hari. Dan akuifer produktif sedang dengan persebaran luas: Akuifer dengan aliran melalui ruang antar butir, akuifer ini tersusun oleh formasi aluvium yang terdiri atas material berukuran lempung, lanau, pasir, kerikil dan brangkal dengan nilai kelulusan $1,3 \mathrm{~m} / \mathrm{hari}$ (Gambar 4).

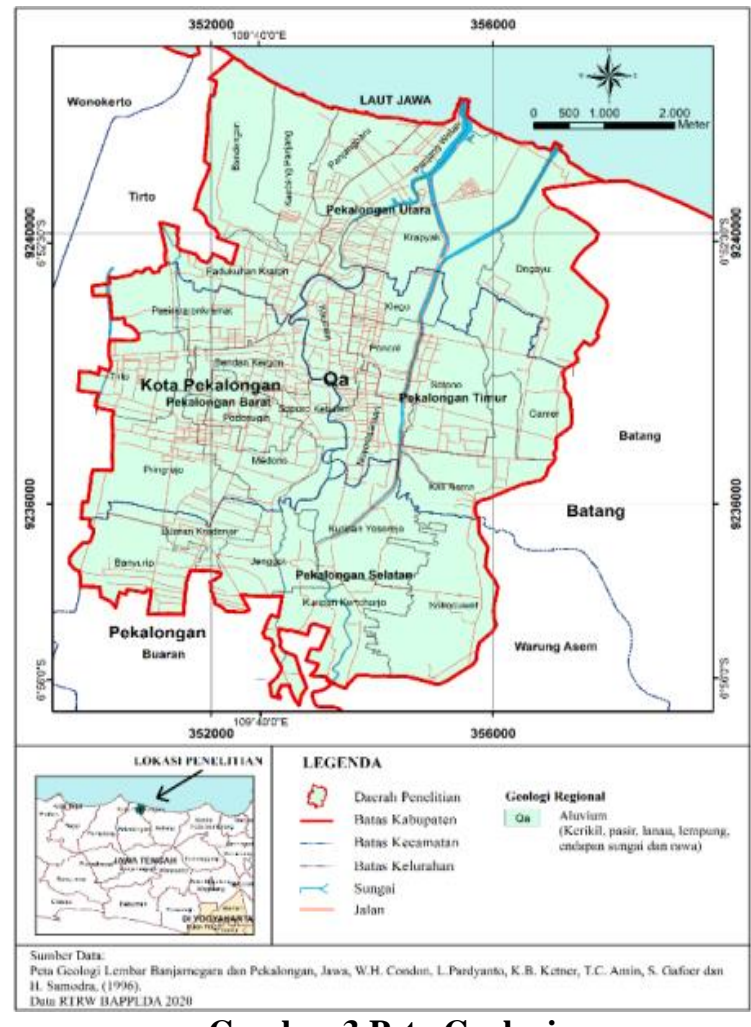

\section{Gambar 3 Peta Geologi}

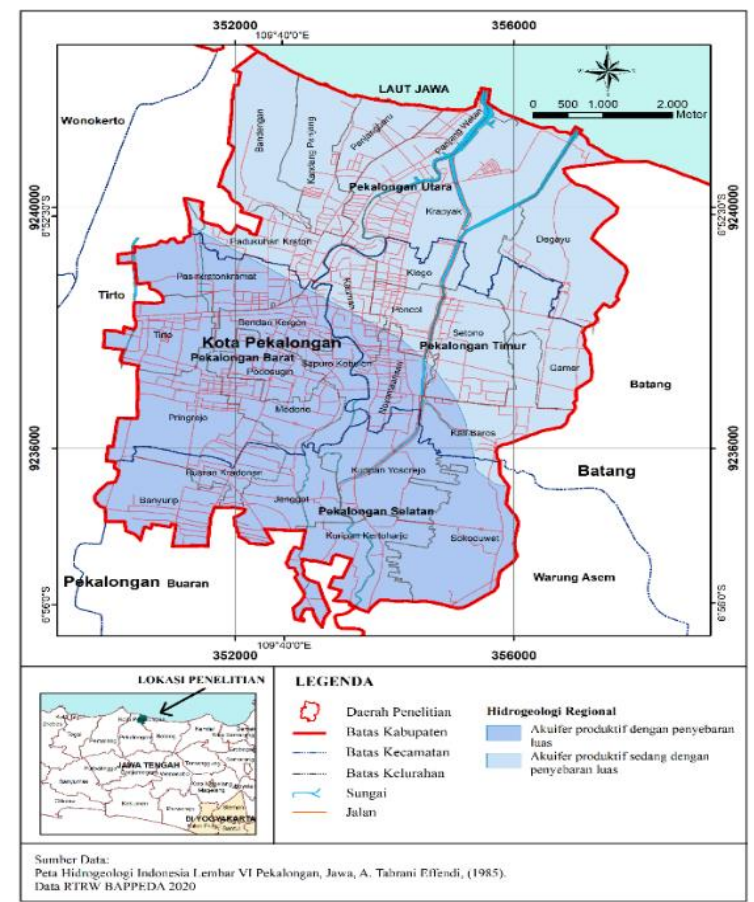




\section{Gambar 4 Peta Hidrogeologi}

Jenis tanah yang terdapat di Kota Pekalongan antara lain adalah aluvial dan kipas aluvial. Jenis tanah aluvial tersebar di wilayah pesisir dengan muka tanah rendah, selebihnya memiliki jenis tanah kipas aluvial (Gambar 5). Tekstur tanah yang berbutir kasar memiliki porositas yang lebih tinggi sehingga kemampuan tanah untuk meloloskan air atau menyerap air akan semakin besar dibandingkan dengan yang tekstur tanahnya lempung memiliki porositas kecil sehingga laju infiltrasi kecil (Norfadilah, dkk., 2020).

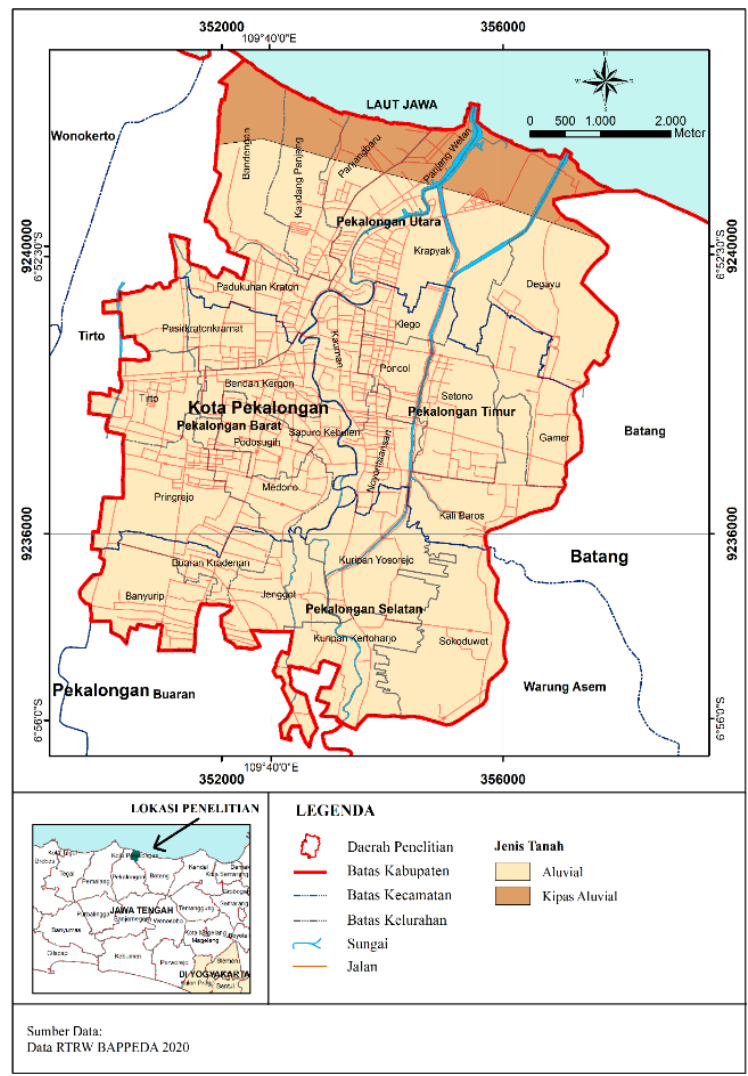

Gambar 5 Peta Jenis Tanah

\section{METODOLOGI PENELITIAN}

Penelitian ini dilakukan di Kota Pekalongan yang memiliki 27 kelurahan, 337 Rukun Warga dan 1.640 Rukun Tetangga. Metode yang digunakan dalam penelitian ini adalah metode pengumpulan data yaitu pengumpulan data sekunder, pengumpulan data primer meliputi pemetaan hidrogeologi secara menyeluruh dalam hal ini pengukuran kedalaman muka air tanah akuifer bebas (shallow wells dan intermediate wells), survei geologi permukaan (litologi permukaan, morfologi) dan analisis spasial berbasis sistem informasi geografis (Arc GIS 10.4). Metode ini telah banyak digunakan oleh para peneliti karena efektif dan efisien.

\section{HASIL DAN PEMBAHASAN \\ 4.1. Tata Guna Lahan}

Penggunaan tanah di Kota Pekalongan dibedakan menjadi tanah sawah dan tanah kering. Tanah sawah luasnya setiap tahun berkurang, sebaliknya tanah kering mengalami peningkatan perluasan. Di Kota Pekalongan terdapat banyak penggunaan lahan sebagai lahan budidaya perikanan darat dan pertanian. Untuk budidaya perikanan darat meliputi tambak (payau) dan kolam ikan (tawar). Untuk keberadaan perikanan darat di Kota Pekalongan setiap tahunnya mengalami penambahan, khusus untuk tambak yang terdapat di Kecamatan Pekalongan Utara dan setiap tahunnya selalu mengalami penambahan luas. (Gambar 6).

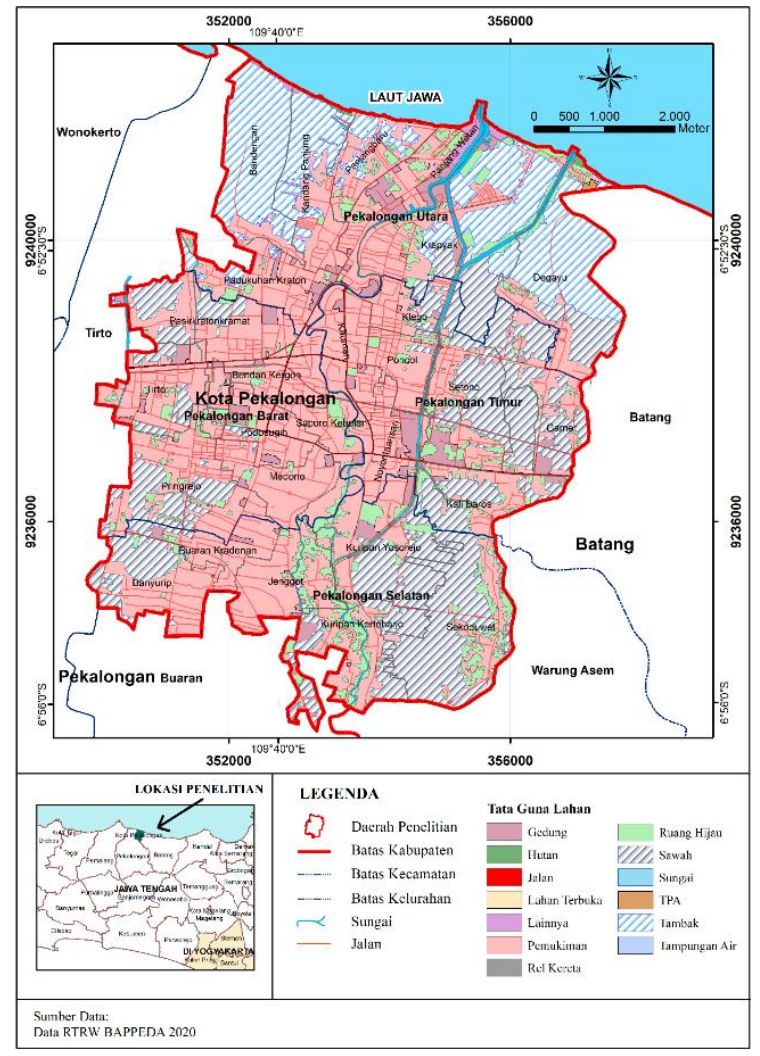

Gambar 6 Peta Tata Guna Lahan 


\subsection{Kedalaman Muka Air Tanah}

Berdasarkan hasil pengukuran di lapangan didapatkan kedalaman muka air tanah Kota Pekalongan diklasifikasikan dalam 3 (tiga) level yaitu 0 - 1,5 meter; $1,5-3$ meter; dan di atas 3 meter (Gambar 7). Pekalongan bagian utara, timur dan barat memiliki kedalaman muka air tanah tidak lebih dari 1,5 meter. Sedangkan Pekalongan Selatan memiliki ketiga level kedalaman muka air tanah tersebut.

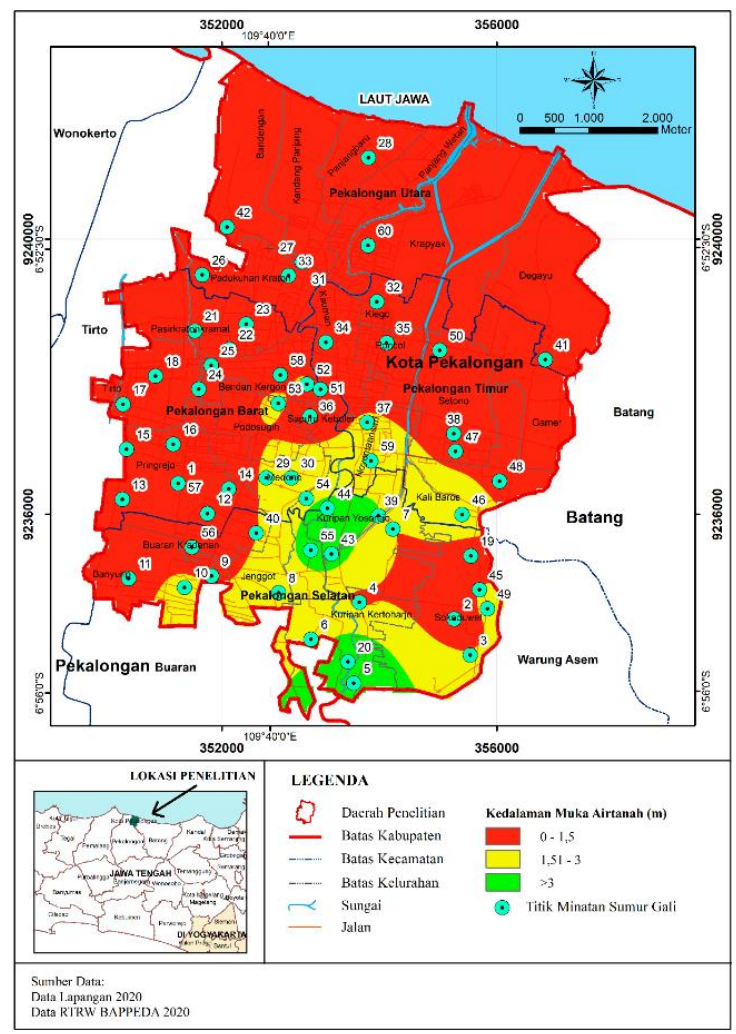

Gambar 7 Peta Kedalaman Muka Air Tanah

\subsection{Penentuan Debit Andil dan Kedalaman Sumur Resapan Air Hujan}

Dalam pembuatan sumur resapan membutuhkan adanya bidang tadah sebagai pengumpul air hujan. Luasan bidang tadah dalam hal ini berupa luas bangunan atau gedung. Bidang tadah yang dihitung memiliki beberapa asumsi, seperti yang ditunjukkan pada
Tabel 3 - 6, yang dijabarkan poin-poin sebagai berikut.

a) Luas bidang tadah merupakan luas Kota Pekalongan secara umum;

b) Luas bidang tadah dibagi per kecamatan di Kota Pekalongan secara umum;

c) Luas bidang tadah adalah luas Kota Pekalongan dengan muka air tanah $>1,5 \mathrm{~m}$;

d) Luas bidang tadah adalah Kota Pekalongan dengan tata guna lahan terbangun dengan muka air tanah >1,5 m;

e) Luas bidang tadah adalah Kota Pekalongan dengan muka air tanah $>1,5$ yang diintegrasikan dengan data banjir;

f) Luas bidang tadah adalah Kota Pekalongan dengan tata guna lahan permukiman dan muka air tanah >1,5 yang diintegrasikan dengan data banjir;

g) Luas bidang tadah adalah pembagian per kecamatan di Kota Pekalongan dengan tata guna lahan

\subsection{Curah hujan}

Curah hujan dibedakan menjadi tiga kelas, yakni curah hujan rendah $(<1.500 \mathrm{~mm} / \mathrm{tahun})$, curah hujan menengah (1.500-2.500 $\mathrm{mm} /$ tahun), dan curah hujan tinggi $(>2.500$ $\mathrm{mm} /$ tahun). Analisis yang dilakukan di wilayah Kota Pekalongan menggunakan data curah hujan dalam 10 tahun terakhir, yakni dari tahun 2010 hingga tahun 2019. Rata-rata jumlah curah hujan tersebut sebesar 2.180,40 $\mathrm{mm} / \mathrm{tahun}$, yang mana termasuk dalam curah hujan menengah.

Analisis curah hujan dilakukan dengan menggunakan probabilitas normal dengan rumus $\mathrm{XT}=\mathrm{X}+\mathrm{K} * \mathrm{~s}$, di mana

XT : hujan rencana dengan periode ulang T tahun

$\mathrm{X} \quad$ : nilai rata-rata dari data hujan $(\mathrm{mm})$

$\mathrm{K}$ : faktor frekuensi, dengan nilai tergantung pada $\mathrm{T}$

S : standar deviasi dari data hujan $(\mathrm{mm})$

Tabel 3 Luas Bidang Tadah Asumsi poin a - b

\begin{tabular}{ccccc}
\hline No & Wilayah Kecamatan & Permukiman $\left(\mathbf{m}^{\mathbf{2}}\right)$ & Gedung $\left(\mathbf{m}^{\mathbf{2}}\right)$ & Total $\left(\mathbf{m}^{\mathbf{2}}\right)$ \\
\hline 1. & Pekalongan Utara & $4.878 .790,53$ & $577.703,79$ & $5.456 .494,32$ \\
2. & Pekalongan Barat & $7.014 .602,36$ & $412.931,55$ & $7.427 .533,91$ \\
3. & Pekalongan Timur & $4.645 .613,62$ & $571.948,83$ & $5.217 .562,45$ \\
4. & Pekalongan Selatan & $4.939 .819,48$ & $302.029,37$ & $5.241 .848,84$ \\
5. & Kota Pekalongan & $21.478 .849,62$ & $1.864 .613,54$ & $23.343 .463,16$ \\
\hline
\end{tabular}


Tabel 4 Luas Bidang Tadah Asumsi poin c - f'

\begin{tabular}{clr}
\hline No & \multicolumn{1}{c}{ Wilayah Kota Pekalongan } & \multicolumn{1}{c}{ Luas $\left(\mathbf{m}^{2}\right)$} \\
\hline 1 & Wilayah dengan MAT $>1.5 \mathrm{~m}$ & $10.479 .462,26$ \\
2 & Bangunan dengan MAT $>1.5 \mathrm{~m}$ & $5.859 .484,71$ \\
3 & Wilayah dengan MAT $>1.5 \mathrm{~m}$ yang Terdampak Banjir & $1.235 .263,45$ \\
4 & Bangunan dengan MAT $>1.5$ m yang Terdampak Banjir & $1.183 .416,21$ \\
\hline
\end{tabular}

Tabel 5 Luas Bidang Tadah Asumsi poin d per kecamatan

\begin{tabular}{clrr}
\hline No & Kecamatan & Bangunan $\left(\mathbf{m}^{2}\right)$ & Total Luas $\left(\mathbf{m}^{\mathbf{2}}\right)$ \\
\hline 1 & Pekalongan Utara & 0,00 & 0,00 \\
2 & Pekalongan Barat & $1.025 .334,59$ & $1.025 .334,59$ \\
3 & Pekalongan Timur & $1.286 .347,45$ & $1.286 .347,45$ \\
& & $99.819,22$ & $99.819,22$ \\
& & $24.304,68$ & $24.304,68$ \\
4 & Pekalongan Selatan & $3.096 .706,03$ & $3.096 .706,03$ \\
& & $271.280,21$ & $271.280,21$ \\
& & $42.445,95$ & $42.445,95$ \\
5 & Kota Pekalongan & $5.846 .238,13$ & $5.846 .238,13$ \\
\hline
\end{tabular}

Tabel 6 Luas bidang tadah asumsi poin g (bangunan dengan mat $>1.5 \mathrm{~m}$ yang tidak terdampak banjir)

\begin{tabular}{clc}
\hline No & \multicolumn{1}{c}{ Kecamatan } & Bangunan $\left(\mathbf{m}^{\mathbf{2}}\right)$ \\
\hline 1 & Pekalongan Utara & 0,00 \\
2 & Pekalongan Barat & $832.720,49$ \\
3 & Pekalongan Timur & 0,00 \\
4 & Pekalongan Selatan & $350.695,72$ \\
5 & Kota Pekalongan & $1.183 .416,21$ \\
\hline
\end{tabular}

Perhitungan curah hujan secara lebih jelas dapat dilihat pada Tabel 7. Selanjutnya dilakukan perhitungan logaritma hujan tahunan atau banjir periode ulang. Perhitungan dijabarkan sebagai berikut.

Untuk periode ulang 2 tahun, nilai $\mathrm{K}=0$, maka

$$
\begin{aligned}
\mathrm{XT} & =\mathrm{X}+\mathrm{K} * \mathrm{~s} \\
& =184,49+0 * 44,23=184,49
\end{aligned}
$$

Berdasarkan SNI No. 03-2453-2002 perencanaan sumur resapan air menggunakan periode ulang 5 tahun, sehingga perhitungan selanjutnya menggunakan hujan rancangan harian (R24) yakni 221,44 mm/hari. Tabel 8 menunjukkan hujan rencana periode ulang 2,5 , 20, 50, dan 100 tahun.

\section{Tabel 7 Perhitungan curah hujan}

\begin{tabular}{cccc}
\hline Tahun & $\begin{array}{c}\text { Curah Hujan } \\
\mathrm{X}_{\mathrm{i}}(\mathrm{Mm})\end{array}$ & $\left(\mathrm{X}_{\mathrm{i}}-\mathrm{X}\right)$ & $\left(\mathrm{X}_{\mathrm{i}}-\mathrm{X}\right)^{2}$ \\
\hline 2010 & 199,6666667 & 15,38 & 236,44 \\
2011 & 198,42 & 14,13 & 199,56 \\
2012 & 155,40 & $-28,89$ & 834,63 \\
\hline 2013 & 184,00 & $-0,29$ & 0,08 \\
2014 & 288,42 & 104,13 & $10.842,36$ \\
2015 & 178,25 & $-6,04$ & 36,48
\end{tabular}

\begin{tabular}{cccc}
\hline Tahun & $\begin{array}{c}\text { Curah Hujan } \\
\mathrm{X}_{\mathrm{i}}(\mathrm{Mm})\end{array}$ & $\left(\mathrm{X}_{\mathrm{i}}-\mathrm{X}\right)$ & $\left(\mathrm{X}_{\mathrm{i}}-\mathrm{X}\right)^{2}$ \\
\hline 2016 & 206,42 & 22,13 & 489,59 \\
2017 & 137,25 & $-47,04$ & $2.212,76$ \\
2018 & 142,50 & $-41,79$ & $1.746,40$ \\
2019 & 152,58 & $-31,71$ & $1.005,31$ \\
Jumlah & 1.843 & & 17.604 \\
Rata-rata & 184,29 & & \\
Stan Dev & 44,23 & & \\
\hline
\end{tabular}

Tabel 8 Perhitungan hujan rencana melalui periode ulang

\begin{tabular}{llllll}
\hline ta & X & Log X & K & S & XT \\
\hline 2 & 184,29 & 2,265502 & 0 & 44,23 & 184,29 \\
5 & 184,29 & 2,265502 & 0,84 & 44,23 & 221,44 \\
20 & 184,29 & 2,265502 & 1,64 & 44,23 & 256,82 \\
50 & 184,29 & 2,265502 & 2,05 & 44,23 & 274,95 \\
100 & 184,29 & 2,265502 & 2,33 & 44,23 & 287,33 \\
\hline
\end{tabular}

Setelah curah hujan rencana (R24) didapatkan, perhitungan menggunakan metode monobe seperti dalam persamaan (1). Sesuai dengan SNI 8456:2017, lama hujan yang digunakan selama 2 jam, sehingga contoh perhitungan adalah sebagai berikut.

$I=\frac{R_{24}}{24}\left(\frac{24}{t}\right)^{\frac{2}{3}}$ 


$$
\begin{aligned}
I & =\frac{221,44}{24}\left(\frac{24}{2}\right)^{\frac{2}{3}} \\
& =48,36 \mathrm{~mm} / \mathrm{jam}=0,05 \mathrm{~m} / \mathrm{jam}
\end{aligned}
$$

Perhitungan selanjutnya

adalah perhitungan jumlah sumur resapan dengan menghitung debit andil banjir. Rumus yang digunakan yakni menggunakan persamaan $\mathrm{Q}=$ C.I.A, di mana $\mathrm{C}$ bernilai 0,95 dan A merupakan luas bidang tadah dalam $\mathrm{m}^{2}$.

Setelah diketahui nilai $Q$, selanjutnya menghitung $\mathrm{H}$ menggunakan persamaan (2), tergantung pada keadaan tanah dan jenis konstruksi sumur

$$
H=\frac{Q}{\omega \pi r K}
$$

Perhitungan berikut ini diasumsikan bahwa bidang tadah merupakan satu Kota Pekalongan : $\mathrm{A}=23.343 .463,16 \mathrm{~m}^{2}$

$$
\begin{aligned}
\mathrm{Q} & =0,95 * 0,048 * 23.343 .463,16 \\
& =1.072 .476,90
\end{aligned}
$$

$\mathrm{K}=1,8 \times 10^{-2} \mathrm{~cm} /$ detik untuk jenis tanah porus

$$
=0,648 \mathrm{~m} / \mathrm{jam}
$$

$\mathrm{K}=0,02 \mathrm{~m} / \mathrm{jam}$ untuk jenis tanah lanau (SNI 8456-2017)

Penentuan koefisien permeabilitas (K) berdasarkan pada litologi Kota Pekalongan yang merujuk pada Gambar 8 .

$\omega=2$, untuk sumur kosong berdinding kedap air $\omega=5$, untuk sumur kosong berdinding porus

$$
H=\frac{1.072 .476,90}{2 \times 3,14 \times 1 \times 0,648}
$$

$=263.544,1$ kebutuhan dan penempatan sumur resapan per kecamatan. Perhitungan lengkap dapat dilihat pada Tabel 9-16.

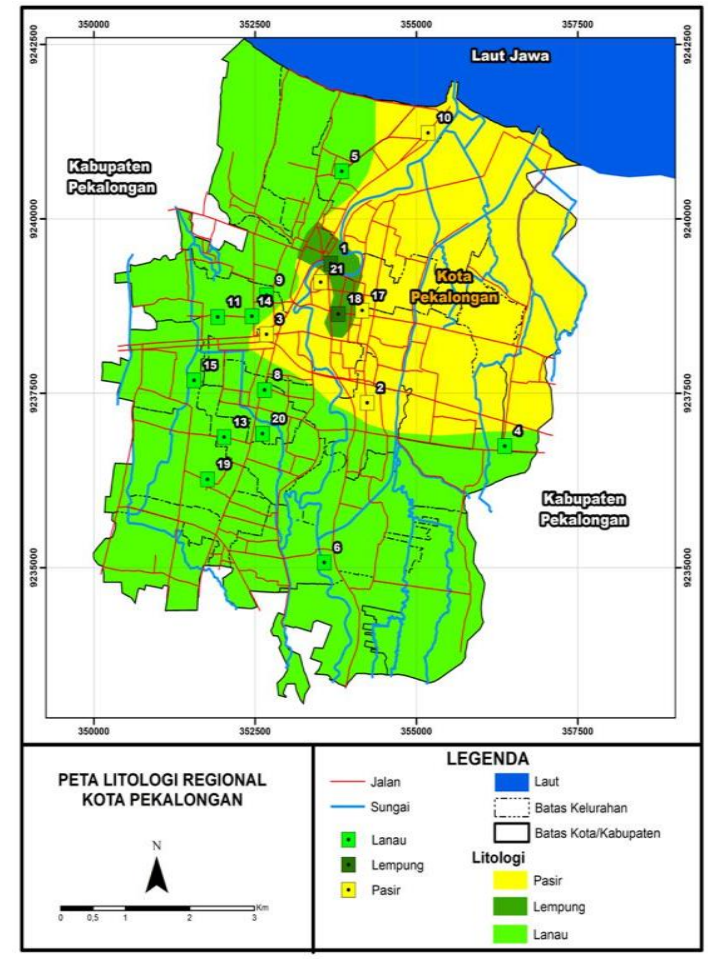

Gambar 8 Peta Litologi Kota Pekalongan

Tabel 9 Perhitungan debit andil (Q) pada asumsi poin (a-b)

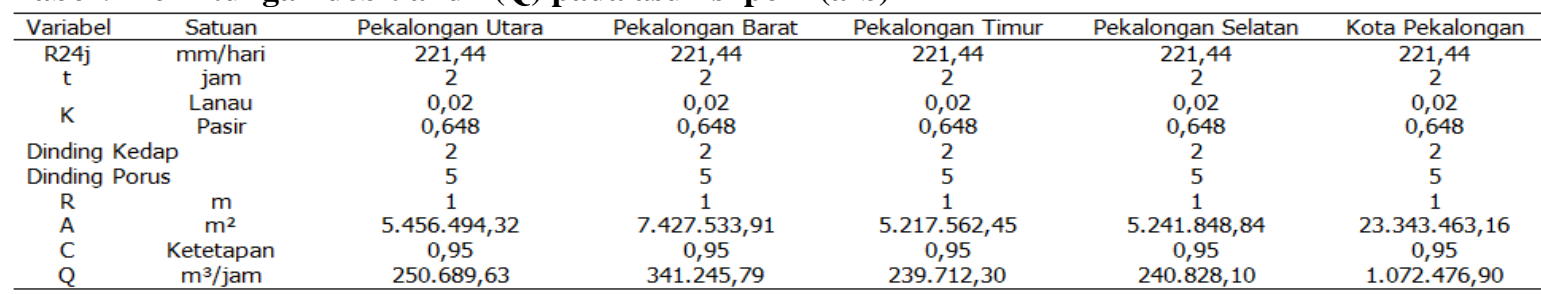

Tabel 10 Perhitungan jumlah sumur $(\mathrm{H})$ pada asumsi poin (a-b)

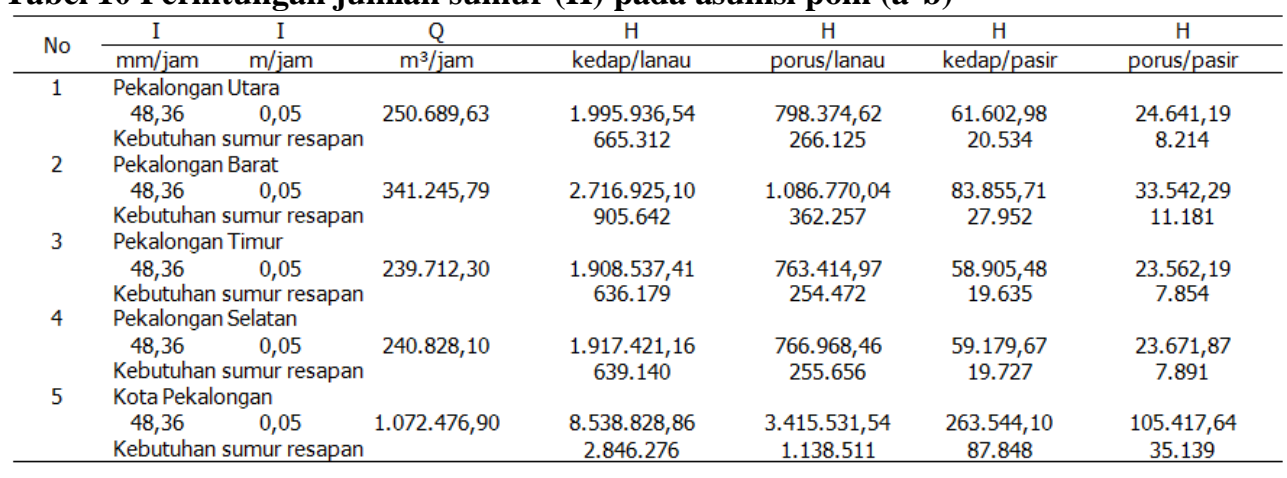


Tabel 11 Perhitungan debit andil (Q) pada asumsi poin (c-f)

\begin{tabular}{|c|c|c|c|c|c|}
\hline Variabel & Satuan & MAT $>1,5 \mathrm{~m}$ & $\begin{array}{c}\text { Bangunan - MAT } \\
>1,5 \mathrm{~m}\end{array}$ & $\begin{array}{c}\text { MAT }>1,5 m \text { - Terdampak } \\
\text { Banjir }\end{array}$ & $\begin{array}{c}\text { Bangunan - MAT >1,5m - Terdampak } \\
\text { Banjir }\end{array}$ \\
\hline R24j & $\mathrm{mm} /$ hari & 221,44 & 221,44 & 221,44 & 221,44 \\
\hline t & jam & 2 & 2 & 2 & 2 \\
\hline \multirow{2}{*}{$\mathrm{K}$} & Lanau & 0,02 & 0,02 & 0,02 & 0,02 \\
\hline & Pasir & 0,648 & 0,648 & 0,648 & 0,648 \\
\hline \multicolumn{2}{|c|}{ Dinding Kedap } & 2 & 2 & 2 & 2 \\
\hline \multicolumn{2}{|c|}{ Dinding Porus } & 5 & 5 & 5 & 5 \\
\hline $\mathrm{R}$ & $\mathrm{m}$ & 1 & 1 & 1 & 1 \\
\hline A & $\mathrm{m}^{2}$ & $10.479 .462,26$ & $5.859 .484,71$ & $1.235 .263,45$ & $1.183 .416,21$ \\
\hline $\mathrm{C}$ & Ketetapan & 0,95 & 0,95 & 0,95 & 0,95 \\
\hline$Q$ & $\mathrm{~m}^{3} / \mathrm{jam}$ & $481.461,61$ & $269.204,36$ & $56.752,14$ & $54.370,11$ \\
\hline
\end{tabular}

Tabel 12 Perhitungan jumlah sumur $(\mathrm{H})$ pada asumsi poin (c-f)

\begin{tabular}{|c|c|c|c|c|c|c|c|}
\hline \multirow{2}{*}{ No } & I & I & Q & $\mathrm{H}$ & $\mathrm{H}$ & $\mathrm{H}$ & $\mathrm{H}$ \\
\hline & $\mathrm{mm} / \mathrm{jam}$ & $\mathrm{m} / \mathrm{jam}$ & $\mathrm{m}^{3} / \mathrm{jam}$ & kedap/lanau & porus/lanau & kedap/pasir & porus/pasir \\
\hline 1 & \multicolumn{7}{|c|}{ Kota Pekalongan dengan MAT >1.5 m } \\
\hline \multirow{5}{*}{2} & 48,36 & 0,05 & $481.461,61$ & $3.833 .293,04$ & $1.533 .317,21$ & $118.311,51$ & $47.324,61$ \\
\hline & Kebutuhan & sumur & esapan & 1.277 .764 & 511.106 & 39.437 & 15.775 \\
\hline & \multicolumn{7}{|c|}{ Kota Pekalongan pada lahan terbangun dengan MAT >1.5 m } \\
\hline & 48,36 & 0,05 & $269.204,36$ & $2.143 .346,80$ & $857.338,72$ & $1.190 .748,22$ & $476.299,29$ \\
\hline & Kebutuhan & sumur & esapan & 714.449 & 285.780 & 396.916 & 158.766 \\
\hline \multirow[t]{3}{*}{3} & \multicolumn{7}{|c|}{ Kota Pekalongan yang terdampak banjir dengan MAT >1.5 m } \\
\hline & 48,36 & 0,05 & $56.752,14$ & $451.848,26$ & $180.739,30$ & $251.026,81$ & $100.410,72$ \\
\hline & Kebutuhan & sumur & esapan & 150.616 & 60.246 & 83.676 & 33.470 \\
\hline \multirow[t]{3}{*}{4} & \multicolumn{7}{|c|}{ Kota Pekalongan pada lahan terbangun yang terdampak banjir dengan MAT > 1.5 m } \\
\hline & 48,36 & 0,05 & $54.370,11$ & $432.883,01$ & $173.153,20$ & $240.490,56$ & $96.196,22$ \\
\hline & Kebutuhan & sumur & esapan & 144.294 & 57.718 & 80.164 & 32.065 \\
\hline
\end{tabular}

Tabel 13 Perhitungan debit andil (Q) pada asumsi poin (d) per kecamatan Kota Pekalongan

\begin{tabular}{|c|c|c|c|c|c|c|}
\hline Variabel & Satuan & Pekalongan Utara & Pekalongan Barat & Pekalongan Timur & Pekalongan Selatan & Kota Pekalongan \\
\hline R24 & $\mathrm{mm} /$ hari & 221,44 & 221,44 & 221,44 & 221,44 & 221,44 \\
\hline $\mathrm{t}$ & jam & 2 & 2 & 2 & 2 & 2 \\
\hline \multirow[t]{2}{*}{ K } & Lanau & 0,02 & 0,02 & 0,02 & 0,02 & 0,02 \\
\hline & Pasir & 0,648 & 0,648 & 0,648 & 0,648 & 0,648 \\
\hline \multicolumn{2}{|c|}{ Dinding kedap } & 2 & 2 & 2 & 2 & 2 \\
\hline \multicolumn{2}{|c|}{ Dinding porus } & 5 & 5 & 5 & 5 & 5 \\
\hline $\mathrm{R}$ & $\mathrm{m}$ & 1 & 1 & 1 & 1 & 1 \\
\hline A & $\mathrm{m}^{2}$ & 0,00 & $1.025 .334,59$ & $1.410 .471,35$ & $3.410 .432,19$ & $5.846 .238,13$ \\
\hline $\mathrm{C}$ & Ketetapan & 0,95 & 0,95 & 0,95 & 0,95 & 0,95 \\
\hline$Q$ & $\mathrm{~m}^{3} / \mathrm{jam}$ & 0,00 & $47.107,31$ & $64.801,78$ & $156.686,68$ & $268.595,77$ \\
\hline
\end{tabular}

Tabel 14 Perhitungan jumlah sumur $(\mathrm{H})$ pada asumsi poin $(\mathrm{d})$ per kecamatan Kota Pekalongan

\begin{tabular}{|c|c|c|c|c|c|c|c|}
\hline \multirow{2}{*}{ No. } & I & I & Q & $\mathrm{H}$ & $\mathrm{H}$ & $\mathrm{H}$ & $\mathrm{H}$ \\
\hline & $\mathrm{mm} / \mathrm{jam}$ & $\mathrm{m} / \mathrm{jam}$ & $\mathrm{m}^{3} / \mathrm{jam}$ & kedap/lanau & porus/lanau & kedap/pasir & porus/pasir \\
\hline \multirow[t]{3}{*}{1} & Pekalongan Utara & & & & & & \\
\hline & 48,36 & 0,05 & 0,00 & 0,00 & 0,00 & 0,00 & 0,00 \\
\hline & Kebutuhan sumur & resapan & & 0 & 0 & 0 & 0 \\
\hline \multirow[t]{3}{*}{2} & Pekalongan Barat & & & & & & \\
\hline & 48,36 & 0,05 & $47.107,31$ & $375.058,17$ & $150.023,27$ & $11.575,87$ & $4.630,35$ \\
\hline & Kebutuhan sumur & resapan & & 125.019 & 50.008 & 3.859 & 1.543 \\
\hline \multirow[t]{3}{*}{3} & Pekalongan Timur & & & & & & \\
\hline & 48,36 & 0,05 & $64.801,78$ & $515.937,73$ & $206.375,09$ & $15.924,00$ & $6.369,60$ \\
\hline & Kebutuhan sumur & resapan & & 171.979 & 68.792 & 5.308 & 2.123 \\
\hline \multirow[t]{3}{*}{4} & Pekalongan Selat & & & & & & \\
\hline & 48,36 & 0,05 & $156.686,68$ & $1.247 .505,42$ & $499.002,17$ & $38.503,25$ & $15.401,30$ \\
\hline & Kebutuhan sumur & resapan & & 415.835 & 166.334 & 12.834 & 5.134 \\
\hline \multirow[t]{3}{*}{5} & Kota Pekalongan & & & & & & \\
\hline & 48,36 & 0,05 & $268.595,77$ & $2.138 .501,32$ & $855.400,53$ & $66.003,13$ & $26.401,25$ \\
\hline & Kebutuhan sumur & resapan & & 712.834 & 285.134 & 22.001 & 8.800 \\
\hline
\end{tabular}


Tabel 15 Perhitungan debit andil (Q) pada asumsi poin (g) per kecamatan Kota Pekalongan

\begin{tabular}{|c|c|c|c|c|c|c|}
\hline Variabel & Satuan & Pekalongan Utara & Pekalongan Barat & Pekalongan Timur & Pekalongan Selatan & Kota Pekalongan \\
\hline R24 & $\mathrm{mm} /$ hari & 221,44 & 221,44 & 221,44 & 221,44 & 221,44 \\
\hline $\mathrm{t}$ & jam & 2 & 2 & 2 & 2 & 2 \\
\hline \multirow[t]{2}{*}{ K } & Lanau & 0,02 & 0,02 & 0,02 & 0,02 & 0,02 \\
\hline & Pasir & 0,648 & 0,648 & 0,648 & 0,648 & 0,648 \\
\hline \multicolumn{2}{|c|}{ Dinding kedap } & 2 & 2 & 2 & 2 & 2 \\
\hline \multicolumn{2}{|c|}{ Dinding porus } & 5 & 5 & 5 & 5 & 5 \\
\hline $\mathrm{R}$ & $\mathrm{m}$ & 1 & 1 & 1 & 1 & 1 \\
\hline A & $\mathrm{m}^{2}$ & 0,00 & $832.720,49$ & 0,00 & $350.695,72$ & $1.183 .416,21$ \\
\hline $\mathrm{C}$ & Ketetapan & 0,95 & 0,95 & 0,95 & 0,95 & 0,95 \\
\hline $\mathrm{Q}$ & $\mathrm{m}^{3} / \mathrm{jam}$ & 0,00 & $38.257,97$ & 0,00 & $16.112,14$ & $54.370,11$ \\
\hline
\end{tabular}

Tabel 16 Perhitungan jumlah sumur $(\mathrm{H})$ pada asumsi poin $(\mathrm{g})$ per kecamatan Kota Pekalongan

\begin{tabular}{|c|c|c|c|c|c|c|c|}
\hline \multirow{2}{*}{ No. } & $\mathrm{I}$ & $\mathrm{I}$ & $\mathrm{Q}$ & $\mathrm{H}$ & $\mathrm{H}$ & $\mathrm{H}$ & $\mathrm{H}$ \\
\hline & $\mathrm{mm} / \mathrm{jam}$ & $\mathrm{m} / \mathrm{jam}$ & $\mathrm{m}^{3} / \mathrm{jam}$ & kedap/lanau & porus/lanau & kedap/pasir & porus/pasir \\
\hline 1 & \multicolumn{7}{|c|}{ Pekalongan Utara } \\
\hline & 48,36 & 0,05 & 0,00 & 0,00 & 0,00 & 0,00 & 0,00 \\
\hline \multirow[t]{2}{*}{2} & $\begin{array}{l}\text { Kebutuhan sumur } \\
\text { Pekalongan Barat }\end{array}$ & r resapan & & 0 & 0 & 0 & 0 \\
\hline & 48,36 & 0,05 & $38.257,97$ & $304.601,67$ & $121.840,67$ & $9.401,29$ & $3.760,51$ \\
\hline \multirow[t]{3}{*}{3} & $\begin{array}{l}\text { Kebutuhan sumur } \\
\text { Pekalongan Timur }\end{array}$ & r resapan & & 101.534 & 40.614 & 3.134 & 1.254 \\
\hline & 48,36 & 0,05 & 0,00 & 0,00 & 0,00 & 0,00 & 0,00 \\
\hline & $\begin{array}{l}\text { Kebutuhan sumur } \\
\text { Pekalongan Selata }\end{array}$ & $\begin{array}{l}\text { resapan } \\
\tan \end{array}$ & & 0 & 0 & 0 & 0 \\
\hline 4 & $\begin{array}{l}48,36 \\
\text { Kebutuhan sumur } \\
\text { Kota Pekalongan }\end{array}$ & $\begin{array}{l}0,05 \\
\text { resapan }\end{array}$ & $16.112,14$ & $\begin{array}{c}128.281,34 \\
42.760\end{array}$ & $\begin{array}{c}51.312,54 \\
17.104\end{array}$ & $\begin{array}{c}3.959,30 \\
1.320\end{array}$ & $\begin{array}{c}1.583,72 \\
528\end{array}$ \\
\hline 5 & $\begin{array}{l}48,36 \\
\text { Kebutuhan sumur }\end{array}$ & $\begin{array}{l}0,05 \\
\text { resapan }\end{array}$ & $54.370,11$ & $\begin{array}{c}432.883,01 \\
144.294\end{array}$ & $\begin{array}{c}173.153,20 \\
57.718\end{array}$ & $\begin{array}{c}13.360,59 \\
4.454\end{array}$ & $\begin{array}{c}5.344,23 \\
1.781\end{array}$ \\
\hline
\end{tabular}

4.4. Kebutuhan Dan Penempatan Sumur Resapan Per Kecamatan

Berdasarkan perhitungan debit andil dan kedalaman sumur resapan air hujan (SRAH) yang dibutuhkan serta karakteristik wilayah
Kota Pekalongan maka direkomendasikan penempatan sumur resapan pada wilayah terbangun dengan kedalaman muka air tanah lebih dari 1,5 meter dengan prioritas wilayah rawan banjir disajikan pada Tabel 17-20

Tabel 17 Rekomendasi penempatan awal sumur resapan air hujan di Kecamatan Pekalongan Barat

\begin{tabular}{ccccc}
\cline { 1 - 3 } KECAMATAN & LUAS $\left(\mathrm{m}^{2}\right)$ & JUMLAH SRAH & \multirow{2}{*}{ KELURAHAN } & KEDALAMAN SRAH $(\mathrm{m})$ \\
\cline { 1 - 3 } Pekalongan Barat & 1.025 .335 & 50.008 & Medono & 2 \\
PB_1 & 23.017 & 230 & Medono & 2 \\
PB_2 & 7.887 & 79 & Podosugih & 1,5 \\
PB_3 & 3.331 & 33 & Podosugih & 1,5 \\
PB_4 & 3.799 & 38 & Medono & 1,5 \\
PB_5 & 3.721 & 37 & Podosugih & 1,5 \\
PB_6 & 12.569 & 126 & Bendan Kergon & 1,5 \\
PB_7 & 3.357 & 34 & & \\
& JUMLAH & 577 unit SRAH & & \\
\hline
\end{tabular}


Tabel 18 Rekomendasi penempatan awal sumur resapan air hujan di Kecamatan Pekalongan Timur

\begin{tabular}{ccccc}
\cline { 1 - 2 } KECAMATAN & LUAS $\left(\mathrm{m}^{2}\right)$ & JUMLAH SRAH & \multirow{2}{*}{ KELURAHAN } & \multirow{2}{*}{ KEDALAMAN SRAH $(\mathrm{m})$} \\
\cline { 1 - 2 } Pekalongan Timur & 1.410 .471 & 68.792 & & \\
PT_1 & 2.579 & 26 & Noyotaansari & 1,5 \\
PT_2 & 2.478 & 25 & Noyotaansari & 1,5 \\
PT_3 & 15.083 & 151 & Noyotaansari & 1,5 \\
PT_4 & 10.597 & 106 & Noyotaansari & 1,5 \\
PT_5 & 2.284 & 23 & Kali Baros & 1,5 \\
PT_6 & 2.874 & 29 & Kali Baros & 1,5 \\
& JUMLAH & 359 unit SRAH & & \\
\hline
\end{tabular}

Tabel 19 Rekomendasi penempatan awal sumur resapan air hujan di Kecamatan Pekalongan Selatan

\begin{tabular}{|c|c|c|c|c|}
\hline KECAMATAN & LUAS $\left(\mathrm{m}^{2}\right)$ & JUMLAH SRAH & \multirow{2}{*}{ KELURAHAN } & \multirow{2}{*}{ KEDALAMAN SRAH (m) } \\
\hline Pekalongan Selatan & 3.410 .432 & 166.334 & & \\
\hline PS_1 & 14.470 & 145 & Banyurip & 1,5 \\
\hline PT_2 & 6.158 & 62 & Jenggot & 2 \\
\hline $\mathrm{PT} \_3$ & 4.331 & 43 & Jenggot & 1,5 \\
\hline $\mathrm{PT} \_4$ & 3.018 & 30 & Buaran Kradenan & 1,5 \\
\hline $\mathrm{PT} \_5$ & 2.254 & 23 & Buaran Kradenan & 1,5 \\
\hline PT_6 & 4.607 & 46 & Jenggot & 2 \\
\hline PT_7 & 5.235 & 52 & Kuripan Yosorejo & 3 \\
\hline $\mathrm{PT} \_8$ & 1.662 & 17 & Kuripan Yosorejo & 3 \\
\hline & JUMLAH & 417 unit SRAH & & \\
\hline
\end{tabular}

Tabel 20 Rekomendasi prioritas penempatan awal sumur resapan air hujan di Kota Pekalongan dalam upaya penanganan banjir

\begin{tabular}{ccccc}
\hline $\begin{array}{c}\text { ZONA } \\
\text { PRIORITAS }\end{array}$ & $\begin{array}{c}\text { LUAS } \\
\left(\mathrm{m}^{2}\right)\end{array}$ & JUMLAH SRAH & KELURAHAN & KEDALAMAN SRAH (m) \\
\hline PB_1 & 23.017 & 230 & Medono & 2 \\
PB_2 & 7.887 & 79 & Medono & 2 \\
PB_3 & 3.331 & 33 & Podosugih & 1,5 \\
PB_4 & 3.799 & 38 & Podosugih & 1,5 \\
PB_5 & 3.721 & 37 & Medono & 1,5 \\
PB_7 & 3.357 & 34 & Bendan Kergon & 1,5 \\
PS_3 & 4.331 & 43 & Juaran Kradenan & 1,5 \\
PS_4 & 3.018 & 30 & Buaran Kradenan & 1,5 \\
PS_5 & 2.254 & 23 & & 1,5 \\
& JUMLAH & 547 unit SRAH & &
\end{tabular}

Dari hasil kajian lapangan yang meliputi kedalaman muka air tanah, daerah terdampak banjir, perhitungan luas lahan terbangun serta data sekunder tata guna lahan, koefisien permeabilitas tanah, maka dapat disusun secara spasial berbasis Sistem Informasi Geografis. Peta rekomedasi lokasi sumur resapan seperti terlihat di Gambar 9. Rekomendasi lokasi sumur resapan terletak pada wilayah dengan kedalaman muka air tanah lebih dari $1,5 \mathrm{~m}$, tidak berada di lokasi terdampak banjir. Zona rekomendasi sumur resapan air hujan terletak di Kecamatan Pekalongan Selatan, Kecamatan Pekalongan Timur dan Kecamatan Pekalongan Barat seperti terlihat di Tabel 17-19. Untuk lokasi prioritas disajikan pada Tabel 20 yang terbagi untuk Kecamatan Pekalongan Barat dan Kecamatan Pekalongan Selatan. Wilayah tersebut memiliki kedalaman muka air tanah antara 1,5-2 m. 


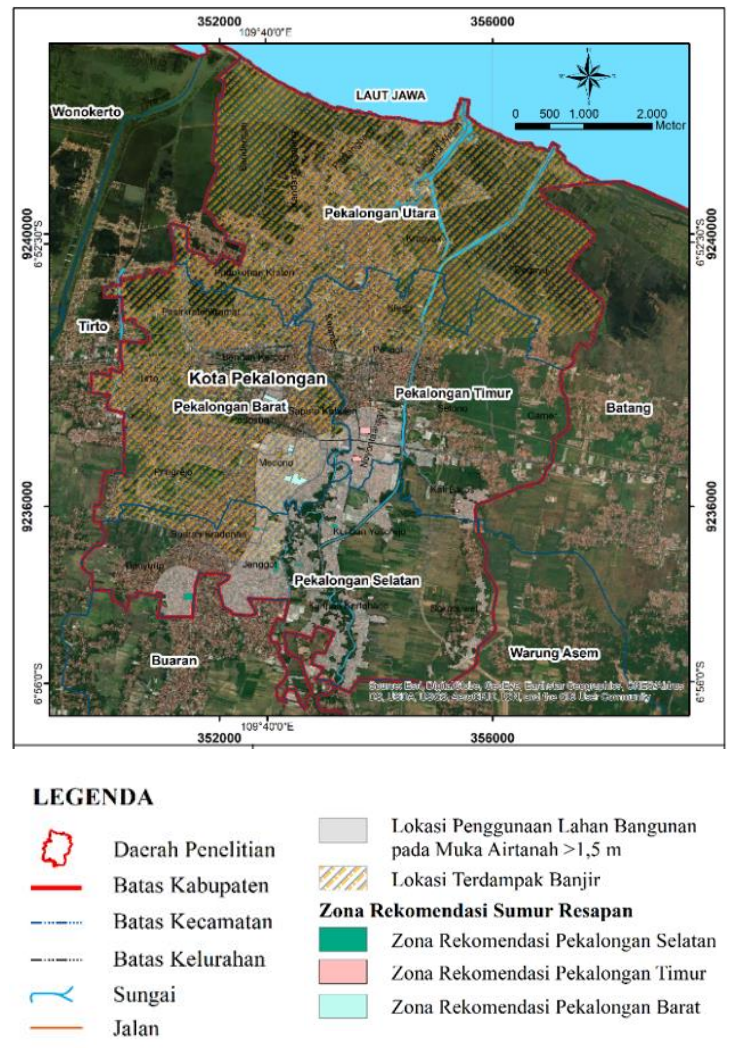

Gambar 9 Peta rekomendasi sumur resapan air hujan berbasis Sistem Informasi Geografis

\section{KESIMPULAN DAN SARAN}

Kesimpulan dari studi potensi dan penentuan sumur resapan sebagai upaya pengendalian banjir di Kota Pekalongan sebagai berikut : kedalaman muka air tanah terdiri dari 1,5 $\mathrm{m}, 1,5-3 \mathrm{~m}$, dan $>3 \mathrm{~m}$. Kebutuhan sumur resapan untuk menampung limpasan dan genangan air hujan pada wilayah rawan banjir Kota Pekalongan yaitu 57.718 unit. Rekomendasi penempatan awal sumur resapan air hujan dalam upaya penanganan banjir dapat dilakukan pada kelurahan Medono, Podosugih, Bendan Kergon, dan Buaran Kradenan dengan 547 unit. Kecamatan Pekalongan Utara dan Pekalongan Timur yang merupakan area rawan banjir namun memiliki kedalaman muka air tanah kurang dari 1,5 meter maka tidak dapat dilakukan instalasi sumur resapan air hujan. Alternatif resapan air hujan pada area dengan kedalaman muka air tanah kurang dari 1,5 meter dapat dilakukan dengan menggunakan parit resapan air hujan dan biopori, serta pemanfaatan air hujan melalui kolam penampungan air hujan atau kolam retensi. Instalasi sumur resapan air hujan pada lahan terbangun dengan kedalaman muka air tanah $>1,5 \mathrm{~m}$ di luar area rawan banjir sebanyak 227.416 unit dengan kedalaman sumur antara 1,5 hingga 4 meter. Dari rekomendasi sumur resapan yang dihasilkan disarankan untuk menindak lanjuti hasil penelitian dengan mengecek kembali lokasi rekomendasi penempatan sumur dengan memperhatikan persyaratan umum dan teknis serta diintegrasikan dengan kebijakan pembangunan Kota Pekalongan seperti sebagian dari Ketentuan Umum Peraturan Zonasi (KUPZ) Rencana Tata Ruang (RTR) Kota Pekalongan untuk tercapainya pembangunan sumur resapan dalam mengatasi banjir.

\section{DAFTAR PUSTAKA}

Adibah, N., Kahar, S. dan Sasmito, B. (2013) 'Aplikasi Penginderaan Jauh dan Sistem Informasi Geografis Untuk Analisis Daerah Resapan Air (Studi Kasus: Kota Pekalongan)', Jurnal Geodesi Undip, 2(2), pp. 141-153

Badan Pusat Statistik Kota Pekalongan (2019) Kota Pekalongan Dalam Angka 2019. 33750.1902. Pekalongan: BPS Kota Pekalongan.

Condon, W.H., Pardyanto, L., Ketner, K. B., Amin, T. C., Gafoer, S., dan Samodra, H. (1996) 'Peta Geologi Lembar Banjarnegara-Pekalongan', Bandung: Pusat Penelitian dan Pengembangan Geologi.

Effendi, A. T. (1985) 'Peta Hidrogeologi Lembar VI Pekalongan', Bandung: Direktorat Geologi Tata Lingkungan.

George, P. (2011) 'Health impacts of floods', Prehospital and Disaster Medicine, 26(2), p. 137. doi: 10.1017/S1049023X11000148.

IPCC (2014) Climate change 2014: impacts, adaptation, and vulnerability. Summaries, frequently asked questions, and crosschapter boxes. In: A Contribution of Working Group II to the Fifth Assessment Report of the Intergovernmental Panel on Climate Change. 
Kartika, F. D. S., Helmi, M. dan Amirudin (2019) 'Meta-analysis of community's adaptation pattern with tidal flood in Pekalongan City, Central Java, Indonesia', E3S Web of Conferences, 125(201 9), pp. 1-4. doi: 10.1051/e3sconf/201912509001.

Mitrović, V. L., O’Mathúna, D. P. dan Nola, I. A. (2019) 'Ethics and Floods: A Systematic Review', Disaster Medicine and Public Health Preparedness, 13(4), pp. 817-828. doi: 10.1017/dmp.2018.154.

Muliawati, D. N. dan Mardyanto, M. A. (2015) 'Perencanaan Penerapan Sistem Drainase Berwawasan Lingkungan (Eko-Drainase) Menggunakan Sumur Resapan Di Kawasan Rungkut', Jurnal Teknik ITS, 4(1), pp. D16-D20. Available at: http://ejurnal.its.ac.id/index.php/teknik/arti cle/view/8833.

Norfadilah, I., Dwiatmoko, M. U. dan Novianti, Y. S. (2020) 'Laju Infiltrasi Pada Danau Bekas Tambang Alluvial Yang Dipengaruhi Karakteristik Sifat Fisik Tanah', Jurnal Himasapta, 5(1), pp. 1317. doi: $10.20527 /$ jhs.v5i1.2047.

Parida, Y. (2019) 'Economic impact of floods in the Indian states', Environment and Development Economics, pp. 1-24. doi: 10.1017/s1355770x 19000317.

Pratama, M. B. (2019) 'Tidal Flood in Pekalongan: Utilizing and Operating Open Resources for Modelling', in IOP Conference Series: Materials Science and Engineering PAPER. IOP Publishing Ltd, pp. $\quad 1-10$. doi: 10.1088/1757899X/676/1/012029.

Putranto, T. T., Widiarso, D. A. dan Yuslihanu, F. (2016) 'Studi Kerentanan Airtanah Terhadap Kontaminan Menggunakan Metode Drastic di Kota Pekalongan', Teknik, 37(1), pp. 26-31. doi: 10.14710/teknik.v37i1.9637.

SNI 03-2453-2002. (2002) 'Tata Cara Perencanaan Sumur Resapan Air Hujan Untuk Lahan Pekarangan', Jakarta: Badan Standarisasi Nasional.

SNI 8456-2017. (2017) 'Sumur dan parit resapan air hujan', Jakarta: Badan Standarisasi Nasional.

Yoda, T., Yokoyama, K., Suzuki, H., dan Hirao, T. (2017) 'Relationship between Long-term Flooding and Serious Mental Illness after the 2011 Flood in Thailand', Disaster Medicine and Public Health Preparedness, 11(3), pp. 300-304. doi: 10.1017/dmp.2016.148.

Yulianto, F., Suwarsono., Maulana, T., dan Khomarudin, M. R. (2019) 'Analysis of the dynamics of coastal landform change based on the integration of remote sensing and gis techniques: Implications for tidal flooding impact in pekalongan, central Java, Indonesia', Quaestiones Geographicae, 38(3), pp. 17-29. doi: 10.2478/quageo-2019-0025.

Zuidam, van. (1983) 'Guide to Geomorphologic aerial photographic interpretation and mapping', ITC Enschede The Nederland. 